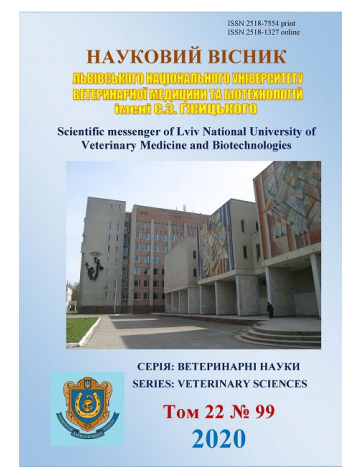

Науковий вісник Дьвівського національного університету ветеринарної медицини та біотехнодогій імені С.3. Гжицького. Серія: Ветеринарні науки

\author{
Scientific Messenger of Lviv National University \\ of Veterinary Medicine and Biotechnologies. \\ Series: Veterinary sciences
}

\title{
Peculiarities of bee breeding influence in mixed form of infectious diseases with varroatosis in the conditions of greenhouse of bees
}

\author{
D. O. Kisil, T. I. Fotina, A. V. Berezovsky, S. M. Nazarenko, J. E. Klishcheva \\ Sumy National Agrarian University, Sumy, Ukraine
}

Article info

Received 16.09.2020

Received in revised form 19.10.2020

Accepted 20.10.2020

Sumy National Agrarian University, G. Kondrat'eva, 160 Sumy, 40000, Ukraine. Tel.: +38-095-495-29-33 E-mail: tif_ua@meta.ua
Kisil, D. O., Fotina, T. I., Berezovsky, A. V., Nazarenko, S. M., \& Klishcheva, J. E. (2020). Peculiarities of bee breeding influence in mixed form of infectious diseases with varroatosis in the conditions of greenhouse of bees. Scientific Messenger of Lviv National University of Veterinary Medicine and Biotechnologies. Series: Veterinary sciences, 22(99), 177-181. doi: $10.32718 /$ nvlvet 9927

The article presents data on our study of the epizootiological situation in apiaries with a mixed form of bee diseases in greenhouses of farms in Sumy region. The data showed that of the previously identified infectious diseases of bees, which are one of the most common in the world - it's actually 4-5 major diseases, of which we studied American rot and ascospherosis, which are manifested in a mixed form with varroasis. Effective control of infectious diseases and early preventive work by a beekeeper in apiaries is a guarantee of a prepared strong bee family both for honey collection and preparation of a bee nest for wintering. Earlier, we conducted a study to monitor the epizootic situation of mixed infectious diseases of bees in the north - eastern region of Ukraine, where a large part of the epizootic was due to ascospherosis American and European rot in field work of bees. But in greenhouse conditions, where high humidity and crowding of bees increases the likelihood of damage by both American rot and ascospherosis. Given these factors, there was a suspicion of a synergistic effect of contamination of bee colonies with the above diseases indoors, damp and isolated. Which led us to the necessary detailed study of these diseases in the greenhouse of bee colonies in the Sumy region in the winter - spring periods of 2020. When examining some samples of printed brood, it was found that, with a strong degree of invasion of varroasis, favorable conditions were created for the accumulation of purulent mass at a sufficiently high level when Bac resistance. Larvae White increased to adverse factors and allowed to affect both weakened and healthy larvae, and with low resistance to developing bees associated with extreme greenhouse conditions and the presence of varroa mites, can sometimes affect bee pupae. After analyzing the results of research, we found that varroa mites contribute to the high development of American rot and ascospherosis in all its forms and witness the role of varroa mites as a factor influencing the intensity of the infectious process in closed and open brood of bee nests.

Key words: bee family, American rot, varroasis, nosematosis, ascospherosis, epizootological situation, greenhouse maintenance, bee.

\section{Особливості ураження бджолиного розплоду при змішаній формі інфекційних хвороб 3 варроатозом в умовах тепличного утримання бджолиних сімей}

\author{
Д. О. Кісіль, Т. І. Фотіна, А. В. Березовський, С. М. Назаренко, Ж. Є. Кліщова \\ Сумський національний аграрний університет, м. Суми, Украӥна
}

У статті наведені дані щодо проведених нами досліджень епізоотологічної ситуащї на пасіках при змішаній формі хвороб
жсіл тепличного утримання господарств Сумської області. Дані показали, щзо з виявлених раніше інфекційних хвороб бджіл, 
сфероз, щуо проявляються в змішаній формі з варроатозом. Ефективна боротьба з інфекційними хворобами та завчасні профілактичні роботи бджолярів на пасіках - це запорука підготовленої сильної бджолиної сім '̈̈ як до медозборів, так і підготовку бджолиного гнізда до зимівлі. Раніме нами було проведено дослідження на моніторинг епізоотичної ситуації щзодо змішаних інфекційних хвороб бджіл у північно-східному регіоні України, де і припадала висока частина епізоотії саме на аскосфероз, американський та європейський гнилець в умовах польових робіт бджіл. Але в тепличних умовах, де підвищена вологість та скупченість бджіл підвищує ймовірність ураження як американським гнильцем, так і аскосферозом. 3 урахуванням иього виникла підозра на синергічний ефект контамінації бджолиних сімей вищеперерахованими хворобами в закритому, вологому та ізольованому приміщенні. Цим і викликана потреба детального вивчення даних хвороб в умовах тепличного утримання бджолиних сімей у Сумській області в зимово-весняний періоди 2020 року. При огляді деяких зразків печатного розплоду було встановлено, шо при сильному ступені інвазї варроатозу виникли сприятливі умови для накопичення гнійної маси на досить високому рівні, коли резистентність Вас. Larvae White збільшилася до несприятливих факторів і дозволила вражати як ослаблені, так $i$ здорові личинки, а при низькій резистентності розвиваються бджоли, пов'язані з екстремальними умовами теплиць і присутністю кліщів варроа, щзо може вражати іноді й лялечки бджіл. Проаналізувавши результати досліджень, ми встановили, що кліщі варроа сприяють досить високому розвитку американського гнильц̧ю та аскосферозу у всіх формах його прояву та є свідченням ролі кліща варроа як чинника, щчо впливає на інтенсивність прояву інфекиійного процесу в закритому та відкритому розплоді гнізда бджіл.

Ключові слова: бджолина сім'я, американський гнилець, варроатоз, нозематоз, аскосфероз, епізоотологічна ситуація, тепличне утримання, бджола.

\section{Встуі}

Відомо, що бджоли є головними запилювачами ентомофільних рослин. Вони виконують майже $80 \%$ всієї обпилювальної роботи, і лише $20 \%$ всіх рослин запилюють джмелі та метелики (Rudenko \& Onenko, 2011; Rudenko, 2011; Es'kov, 2012; Kovalchuk et al., 2019; Vishchur et al., 2019). Медоносні бджоли мають низку переваг в запиленні рослин перед іншими дикими комахами і відіграють велику роль в сільському господарстві. Їх тіло і спосіб життя найбільш пристосовані до виконання цієї функції. Всі медоносні трудівниці живуть і трудяться великими сім'ями, вони створюють великі запаси нектару, інтенсивно і дуже плідно працюють протягом всього свого життєвого циклу. Порівняно з іншими комахами бджоли запилюють в два рази швидше, саме тому їх використовують для цього нелегкого природного процесу (Bogdanov et al., 2007; Luchko, 2012; Rudenko, 2012; Berezovskyi \& Panchev, 2012; Rudenko, 2013; Kovalskyi et al., 2018). Сильні бджолині сім'ї пасічники випускають взимку в теплиці для запилення городніх рослин, навесні в сад на квітучі дерева, влітку на посіви великих медоносних сільськогосподарських угідь і винограду. Але це все залежать від стану і розвитку бджолиної сім’ї. В наш час досить багато досліджень щодо різних форм хвороб бджіл - причин слабкого розвитку бджоли або ж іії повної летальності. Тому перед нами була поставлена мета - вивчення перебігу одних із найпоширеніших хвороб бджіл в змішаній формі американського гнильцю, аскосферозу та варроатозу в умовах тепличного утримання у Сумській області в зимово-весняний періоди 2020 року.

\section{Матеріал і методи досліджень}

Принцип нашого дослідження полягає у вивченні особливостей різних ступенів епізоотичного процесу ураження бджолиних сімей американським гнильцем та аскосферозом при різному ступені ураження бджолиних сімей кліщем Varroa в умовах їхнього тепличного утримання. Вивчали протікання хвороб бджіл у теплицях СТОВ АК “Тепличний” м. Суми Сумської області та на кафедрі ветсанекспертизи, мікробіології, зоогігієни та безпеки і якості продуктів тваринництва Сумського національного аграрного університету за тематичним планом науково-дослідної роботи університету "Впровадження більш досконалих методів діагностики, лікування і профілактики заразних хвороб тварин”, № держреєстрації $0198 \mathrm{U} 001290$ (реєстр. № 41/1).

У попередні діагностичні дослідження включали загальний клінічний огляд гнізда бджолосімей, а також природну загальну оцінку стану відкритого i закритого розплоду бджіл (наявність ураженого розплоду), наявність “строкатості розплоду”, специфічного запаху “столярного клею”, зміненого кольору, виявлення тягучої маси всередині осередків, а також наявність отворів на кришечках печатного розплоду й інших природних поширених клінічних ознак розвитку гнильцю бджолиного розплоду) та огляд ураженості характерний для аскосферозу: личинки 3-4 дня розвитку перетворюються у вапняно-білі тверді грудочки, які прилипають до стінок комірок або вільно лежать у них. Епізоотологічний стан пасіки при американському гнильці та аскосферозі діагностували в умовах Сумського НАУ в лабораторії бджільництва. У лабораторії досліджували відібраний патологічний матеріал: шматочки сот розміром $10 \times 15$ см 3 печатним ураженим розплодом бджолиної сім'ї, перетворених в темну тягучу масу або вже підсохлих та вапняно-білих уражених гіфами гриба Ascosphaera apis прилиплих до стінки комірки уражених личинок бджіл. Особливості епізоотії при варроатозі бджіл, а також змішану форму ураження бджолиної сім’ї при американському гнильці та аскосферозі з варроатозом досліджували при утриманні вуликів в теплицях СТОВ АК “Тепличний” із зимового по весняний періоди включно. Щоб визначити рівень інтенсивності інвазії в бджолиних сім'ях, ми досліджували дорослих бджіл і печатний розплід на наявність кліщів за одним із загальноприйнятих методів лабораторних досліджень патологічного матеріалу бджіл.

Патматеріал, відібраний на пасіці, досліджували відповідно до "Методичних вказівок з лабораторної діагностики американського, європейського гнильцю й парагнильцю бджіл і виділення збудника 3 тонких мазків маси гнильцю" та "Методичних вказівок 3 лабораторної діагностики аскосферозу бджіл і виді- 
ленню збудника з тонких мазків маси або лусочок2-3 штуки", затвердженої Законом України "Про бджільництво” ДСанПіН 8,8,1,2,001 - 98.

\section{Результати та їх обговорення}

Зазначимо, що при слабкій інтенсивності ураження розплоду американським гнильцем та аскосферозом (наявність до 10 уражених личинок на кожній соторамці) змінені поведінка і характер репродуктивної активності самок кліщів порівняно з контрольними групами (група 4 - без видимих клінічних ознак ураження американським гнильцем та група 2 - без видимих клінічних ознак ураженості аскосферозом). Таким чином, якщо в контрольній групі знайшли на соторамках з розплодом кліщів, довільно локалізованих на всіх розплідних рамках, переважно центральній, верхній і передній частині, ближче до виходу бджоли з вулика - до льотка, то в 1 групі самки кліща локалізувалися переважно в центральній частині осередків з розплодом соторамок і відкладали яйця, на виході яких отримували на 38,5 \% більше молодих запліднених самок, незважаючи на те, що перший виходить самець, порівняно з контрольною групою, де американський гнилець не реєстрували. Подібну за ступенем та місцем локалізацію збудника варроатозу виявлено також і в групах, де реєструвався аскосфероз. При такому ураженні бджолиних сімей американським гнильцем уражених личинок спостерігали практично тільки на периферії рамок розплідного гнізда бджіл, чого не можна сказати про ураження розплоду бджіл аскосферозом, де локалізація уражених личинок бджіл спостерігалась фактично на всій соторамці, спостерігали вражені бджолині личинки, переважно трутневі личинки в 3-4-денному віці. Вони вже втратили свою еластичність і перетворились у вапняно-білі тверді грудочки, які в результаті прилипли до стінок комірок або вільно лежали у них. На таблиці 1 зображено загальний стан бджолиних сімей при ураженні змішаною формою акосферозу з варроатозом. Також спостерігали класичну клінічну картину, тобто збудник гнильцю - Bac. Larvae White вражав бджолиних личинок у віці 9-10 діб. При розтині кришечок сот печатного розплоду виявляли гнильну масу уражених предкуколок або лялечок в осередках сот закритого розплоду. У таблиці 2 відображено загальний стан бджолиних сімей при ураженні змішаною формою американського гнильцю з варроатозом.

\section{Таблиця 1}

Загальний стан бджолиних сімей при змішаній формі аскосферозу з варроатозом

\begin{tabular}{cccc}
\hline Група, № & Закліщеність, \% & $\begin{array}{c}\text { Інтенсивність ураження аскосферо- } \\
\text { зом }\end{array}$ & Сила бджолиної сім’ї \\
\hline 1 & $14,9 \pm 1,10$ & середня & 8 рамок $(7$ вулочок $)$ \\
2 & $17,2 \pm 1,23$ & сильна & 7 рамок $(6$ вулочок $)$ \\
3 & $17,2 \pm 1,23$ & сильна & 7 рамок $(6$ вулочок $)$ \\
4 & $25,0 \pm 2,17$ & середня & 7 рамок $(6$ вулочок $)$ \\
5 & $2,3 \pm 1,01$ & слабка & 10 рамок $(9$ вулочок $)$ \\
6 & $2,8 \pm 0,9$ & сильна & 9 рамок $(8$ вулочок $)$ \\
7 & $23,1 \pm 1,03$ & сильна & 5 рамок $(4$ вулочок $)$ \\
8 & $25,0 \pm 2,17$ & середня & 7 рамок $(6$ вулочок $)$ \\
9 & $15,8 \pm 1,25$ & не реєструвалась & 9 рамок $(8$ вулочок $)$ \\
10 & $15,8 \pm 1,25$ & не реєструвалась & 9 рамок $(8$ вулочок $)$ \\
\hline
\end{tabular}

Зазначимо, що наявність інших збудників в бджолиному гнізді стало причиною активізації популяції кліщів, і таким чином виявлявся синергічний ефект взаємодії між даними збудниками. У певних умовах бджолині сім’ї справлялися з ситуацією слабкої закліщенністі, що склалася через невелике зниження сили і продуктивності бджолиної сім’ї. Сім’ї, в яких спостерігалась невелика кількість розплідних соторамок в гнізді вулика і специфічно занижена температура та висока вогкість в гнізді через досить слабку силу бджолиної сім'ї, розмноження кліща Varroa та збудника аскосферозу - Ascosphera apis реєструвалися на рівні максимуму. Сила бджолиних сімей 1-ї, 2-ї та 3-ї групи, в яких реєструвалися середній і високий ступінь інтенсивності ураження аскосферозом, була від 17,9 до 26,4 \% порівняно з бджолиними сім'ями 5-ї та 6-ї дослідних груп. У бджолиних сім'ях 3 1-ї до 3-ї групи спостерігалась досить слабка санітарна робота бджіл в гнізді вулика порівняно з бджолосім'ями 5-ї та 6-ї груп.
Виявляли стрімке зниження розплідних рамок в гнізді фактично до двох соторамок. У першій групі кліщі Varroa реєструвалися в комірках розплоду по декілька паразитів (23,3%). Однак зазначимо, що в цей період збільшилася кількість потомства молодих самок практично без самців, що відповідало літературним даним про здебільшого ураження трутнів в гнізді вулика. Також при огляді спостерігалося, що комірки з личинками, ураженими кліщем Varroa, фактично на всій розплідній соторамці були поруч із затверділими личинками від аскосферозу личинками. Під час огляду 5-ї та 6-ї груп спостерігався високий рівень летальності личинок, які позиційно були поруч з ураженими аскосфеорозом личинками. Подібні показники - і в групах 2 і 3. Під час дослідження розплідної соторамки в групах за номерами 4 та 7 ми виявили, що при досить високому рівні ураженості кліщем Varroa утворювалися сприятливі умови для розвитку гіфів гриба роду Ascosphera відповідно високого рівня, що свідчить про високу резистентність збудника до несприятливих для нього факторів. Таким чином, 
уражатимуться різного фізіологічного стану личинки. Але при низькій резистентності збудника розвиток прилягає на молодих бджіл, враховуючи закриті умови теплиць, де реєстрували кліща Varroa. Бджоли «санітари» в гнізді вулика проводили санітарну очистку вулика від звапнілих загиблих бджіл. Водночас у теплиці спостерігалася повна працездатність бджолиних сімей, запилення тепличних овочевих квіток. Але ми виявили, що в 6-й групі на 34,2 \% менше бджіл були зайняті санітарними роботами, ніж сім'ї в 5-й групі. При слабкій інвазії кліщем Varroa сила бджолиних сімей (6-ї групи) стала фактично на 7,4 \% 3 урахуванням апроксимації слабшою, ніж 5-ї групи. Досліджений нами печатний розплід спостерігався в основному на 4 центральних соторамках.

\section{Таблиця 2}

Загальний стан бджолиних сімей при змішаній формі американського гнильцю з варроатозом

\begin{tabular}{cccc}
\hline Група, № & Закліщеність, \% & $\begin{array}{c}\text { Інтенсивність ураження американським } \\
\text { гнильцем }\end{array}$ & Сила бджолиної сім'ї \\
\hline 1 & $2,3 \pm 1,01$ & слабка & 10 рамок $(9$ вулочок) \\
2 & $2,1 \pm 0,30$ & середня & 9 рамок $(8$ вулочок $)$ \\
3 & $2,8 \pm 0,9$ & сильна & 9 рамок $(8$ вулочок $)$ \\
4 & $2,9 \pm 1,01$ & не реєструвалась & 10 рамок $(9$ вулочок $)$ \\
5 & $14,9 \pm 1,10$ & середня & 8 рамок $(7$ вулочок $)$ \\
6 & $17,2 \pm 1,23$ & сильна & 7 рамок $(6$ вулочок $)$ \\
7 & $15,8 \pm 1,25$ & не реєструвалась & 9 рамок $(8$ вулочок $)$ \\
8 & $25,0 \pm 2,17$ & середня & 7 рамок $(6$ вулочок $)$ \\
9 & $23,1 \pm 1,03$ & сильна & 5 рамок $(4$ вулочок $)$ \\
10 & $20,7 \pm 1,21$ & 8 рамок $(7$ вулочок $)$ \\
\hline
\end{tabular}

При середній інтенсивності ураження (від 10 до 50 загиблих бджолиних личинок на розплідній соторамці) і при сильній інтенсивності ураження (більше ніж 50 уражених бджолиних личинок на розплідній соторамці) американським гнильцем на тлі слабкої інвазії кліщем варроа сила бджолиних сімей (2-а і 3-тя групи) була в середньому на 9,8 і 12,3 \% відповідно слабкішою порівняно 3 1-ю групою. Досліджений печатний розплід виявляли в основному на 4 центральних соторамках. Зазначимо, що комірки розплоду на соторамці з середнім ступенем ураження американським гнильцем рідко реєструвалися і в центральних соторамках з розплодом. У третій групі (з сильною інтенсивністю ураження) уражені личинки траплялися практично на всіз розплідних соторамках. Кліщі варроа локалізували в комірках розплоду, розташовані як поруч з ураженим американським гнильцем, так і в далі від нього. В комірках з розплодом, які були поруч $з$ ураженими личинками, спостерігали на виході потомство кліщів практично тільки молодих самок без самців. Проте вихід молодих самок був на 30,8 \% вищим, ніж у контрольній групі (4-я група).

Бджоли, які містяться всередині вулика, проводили санітарну очистку гніздових, розплідних соторамок від гнільной маси загиблих бджіл. При цьому в теплиці спостерігалося повне збереження працездатності бджолиних сімей, запилення культур огірка та помідора. Але для цих цілей з 2-ї та 3-ї груп бджолиних сімей відпускалося бджіл для роботи на 38,7 i 45,4 \% відповідно менше, ніж 1-ї групи. Бджолині сім'ї з сильною інвазією варроатоза (10-15 \%) і слабким рівнем інтенсивності ураження американським гнильцем не виявлено. Сила бджолиних сімей 5-ї і 6-ї групи (з середнім і високим ступенем інтенсивності ураження американським гнильцем) була в середньому нижчою на 19,6 і 28,7 \% порівняно з сім'ями 2-ї і 3-ї групи. Бджолині сім'ї 5-й і 6-ї груп не могли очи- щати гнійні маси так, як це спостерігалося в сім'ях у 2-й і 3-й групах. Наявність розплоду в гнізді знизилося в середньому до двох соторамок. У 5-й групі при розтині розплоду встановлено, що кліщі траплялися в розплідних комірках як по одній особині $(64,1 \%)$, так і по дві $(23,3$ \%). Однак зазначимо, що в цей час збільшилася кількість потомства молодих самок практично без самців. Так само зазначимо, що ці комірки часто були поруч з ураженими американським гнильцем личинками. При клінічному огляді стану бджолиних сімей 6-ї групи виявлена загибель сусідніх лялечок, розташованих навколо уражених американським гнильцем личинок. При розтині печатного розплоду виявлено, що загибла личинка ще в цілому не перетворилася на гнійну масу, тому можна було встановити приблизний їі вік. Вік загиблих личинки був приблизно від 9 до 11 днів включно. Іноді реєстрували й уражених на початковій стадії і лялечок, приблизно на 12-15 день. В таких комірках виявляли і кліща варpoa. Їх часто спостерігали загиблими.

При загальному огляді стану сімей 6-ї групи виявлено практично ті ж клінічні ознаки, що і в 5-й групі. Крім того, відзначена відвідуваність кліщів як по одній особині, так і групами - по 2 або 3 особині в одну комірку. У 19,5 \% випадків при такій відвідуваності молоді бджоли гинули ще на стадії метаморфозу (лялечки). Це можна розглядати як зараження бджолиного розплоду за допомогою кліщів, контамінованих збудником Bac. Larvae White. Клінічний огляд та біотехнологічний облік проведені в період досліджень, тому нами було виявлено бджолині сім'ї 3 сильною інвазією кліщем $V$. destructor, так само середнього і сильного ступеня ураження Bac. Larvae White. Аналогічно нами було сформовано 3 досліджувані групи.

При огляді деяких зразків печатного розплоду, відібраних з 8-ї і 9-ї груп, було встановлено, що при 
сильному ступені інвазії варроатозу створилися сприятливі умови для накопичення гнійної маси до відносно високого рівня, коли резистентність Bac. Larvae White збільшилася і дозволила вражати як ослаблені, так і здорові личинки, а при низькій резистентності розвиваються бджоли, пов'язані з екстремальними умовами теплиць і присутністю кліщів варроа, що може вражати іноді й лялечки бджіл.

\section{Висновки}

Проаналізовані результати наших досліджень показали, що кліщі варроа сприяють досить високому розвитку американського гнильцю та аскосферозу в усіх формах його прояву і таким чином є свідченням ролі кліща варроа як чинника, що впливає на інтенсивність прояву інфекційного процесу в закритому та відкритому розплоді гнізда бджіл.

Перспективи подальших досліджень. В подальшому плануєтся розробка планових лікувальнопрофілактичних заходів на підставі результатів епізоотичної картини при змішаній формі бджолиних сімей в умовах тепличного утримання.

\section{References}

Berezovskyi, A., \& Panchev, I. I. (2012). Nozematoz yak problemna khvoroba bdzholosimei. Ukrainskyi pasichnyk, 9, 22-24 (in Ukrainian).

Bogdanov, S., Haldimann, M., Luginbuhl, W., \& Gallmann, P. (2007). Minerals in honey: environmental, geographical and botanical aspects. Jornal of Apicultural Research and Bee World, 46(4), 269-275. doi: 10.3896/IBRA.1.46.4.11.

Es'kov, E. K. (2012). Jekologija medonostnoj pchely. Kolos (in Russian).

Kovalchuk, I., Dvylyuk, I., Lecyk, Y., Dvylyuk, I., \& Gutyj, B. (2019). Physiological relationship between content of certain microelements in the tissues of different anatomic sections of the organism of honey bees exposed to citrates of argentum and cuprum. Regulatory Mechanisms in Biosystems, 10(2), 177181. doi: 10.15421/021926.

Kovalskyi, Yu., Gucol, A., Gutyj, B., Sobolev, O., Kovalska, L., \& Mironovych, A. (2018). Features of histolism and hystogenesis in the vital temperature range in the organism of honey bee (Apis mellifera L.) in the postembrional period. Ukrainian Journal of Ecology, 8(2), 301-307. doi: 10.15421/2018_342.

Luchko, M. A. (2012). Bolezni- rasploda pchel. Veterinarija, 6, 9-14 (in Russian).

Rudenko, E.V. (2013). Alternative method of control of infections bee's brood diseases: Apiacta, 38, 93-97. URL: https://www.apimondia.com/docs/apiacta/2003/ rudenko_1.pdf.

Rudenko, Ye. V. (2011). Veterynarno-sanitarni zakhody na pasikakh navesni: Bdzhilnytstvo. K.: Mizh vid. temat. nauk.zb. "Urozhai”, 60-63 (in Ukrainian).

Rudenko, Ye. V. (2012). Biolohichn ipreparaty v system izakhodiv profilaktyky ta likvidatsii infektsiinykh khvorob bdzhil. Veterynarna medytsyna Ukrainy, 4, 42-43 (in Ukrainian).

Rudenko, Ye. V., \& Onenko, V. I. (2011). Prysadybne bdzhilnytstvo: Biblioteka veterynarnoi medytsyny. K. (in Ukrainian).

Vishchur, V. Y., Gutyj, B. V., Nischemenko, N. P., Kushnir, I. M., Salata, V. Z., Tarasenko, L. O., Khimych, M. S., Kushnir, V. I., Kalyn, B. M., Magrelo, N. V., Boiko, P. K., Kolotnytskyy, V. A., Velesyk, T., Pundyak, T. O., \& Gubash, O. P. (2019). Effect of industry on the content of fatty acids in the tissues of the honey-bee head. Ukrainian Journal of Ecology, 9(3), 174-179. URL: https://www.ujecology.com/ abstract/effect-of-industry-on-the-content-of-fatty-acidsin-the-tissues-of-the-honeybee-head-44509.html. 